\title{
PENYULUHAN ADAPTASI TATANAN KEBIASAAN BARU DESA TANGGUH COVID-19
}

${ }^{1}$ Bambang Ari Satria, ${ }^{2}$ Nur Hidayatul Hasanah, ${ }^{3}$ Rudiansyah

${ }^{123}$ Sekolah Tinggi Ilmu Sosial dan Ilmu Politik Pahlawan 12 Sungailiat

Email: bambang.ari.satria@stisipolp12.ac.id

\section{RINGKASAN}

Tatanan kebiasaan baru menjadi isu aktual dalam merespon COVID-19 yang sedang mendera negeri ini. Tatanan kebiasaan baru ini muncul karena proses penyelesaian pandemi tidak bisa dilakukan secara cepat, namun di satu sisi diperlukan acuan untuk masyarakat beradaptasi melakukan kegiatan. Apalagi, saat ini fenomena pandemi bukan saja berpengaruh di sektor kesehatan, tetapi sudah menyerempet ke berbagi sektor di luar kesehatan. Dengan demikian, perlu upaya konkrit untuk memberi pemahaman kepada masyarakat dalam menyikapi tatanan kebiasaan baru tersebut. Pemahaman itu secara perlahan perlu disampaikan ke desa yang statusnya masuk kategori zona hijau COVID-19. Adapun mitra dari pengabdian kepada masyarakat ini adalah relawan desa COVID-19 di Desa Bukit Layang, Kabupaten Bangka. Permasalahan yang dihadapi mitra adalah masih terbatasnya pemahaman dan pengetahuan masyarakat mengenai konsep tatanan kebiasaan baru COVID-19. Desa yang statusnya zona hijau perlu adaptasi terhadap tatanan kebiasaan baru. Saat ini, Kabupaten Bangka merupakan zona merah yang kasus terkonfirmasi positif terbanyak di Provinsi Kepulauan Bangka Belitung. Sebaliknya, Desa Bukit Layang yang berada di Kabupaten Bangka masih dalam zona hijau. Salah satu strategi yang ditawarkan oleh tim adalah memberikan penyuluhan adaptasi tatanan kebiasaan baru desa tangguh COVID-19. Target luaran dari program pengabdian ini adalah peningkatan pengetahuan dan pemahaman masyarakat mengenai konsep tatanan kebiasaan baru di Desa Bukit Layang Kabupaten Bangka. Metode yang digunakan adalah ceramah, diskusi terarah mengenai konsep tatanan kebiasaan baru desa tangguh COVID-19 dan pengisian kuisioner penilaian resiko pribadi terkait COVID-19.

Kata kunci: Adaptasi; Desa Tangguh COVID-19; Kebiasaan Baru

\section{A. Latar Belakang}

\section{1. (Analisis Situasi)}

Pandemi Corona Virus Disease 2019(COVID-19) yang terjadi di Indonesia saat ini menjadi ujian dan pelajaran penting untuk mengukur kekuatan kita dalam berbagai bidang, diantaranya bidang kesehatan, bidang sosial, bidang ekonomi 
hingga tata kelola kebijakan. Dalam perspektif keilmuan administrasi publik, COVID-19 telah melahirkan krisis tata kelola kebijakan dan relasi pusat-daerah belum sesuai harapan dalam hal penanganan. Krisis tata kelola kebijakan penanganan pandemi ditandai oleh beberapa hal, mulai dari kurangnya pemahaman pemerintah dalam memanfaatkan pengetahuan dan data sebagai pijakan awal dalam menyusun kebijakan, adanya keragu-raguan pemerintah untuk mengambil kebijakan yang mendasar guna mencegah dan menangani COVID-19, literasi COVID-19 yang masih terbatas di kalangan masyarakat hingga koordinasi dan sinergi kebijakan yang belum begitu kuat. Selain menyentuh aspek kesehatan, aspek di luar kesehatan seperti dampak sosial-ekonomi sangat tertekan secara massif dan global. Pengetahuan dianggap sebagai posisi penting dalam penyusunan kebijakan penanganan pandemi COVID-19, termasuk isu kebijakan dalam memformulasikan konsep tatanan kebiasaan baru yang aktual saat ini. Peran pengetahuan sangat sentral dalam tata kelola kebijakan penanganan COVID-19 (Amalinda dalam Mas'udi, 2020).

COVID-19 yang terjadi di Indonesia juga sampai ke Provinsi Kepulauan Bangka Belitung. Hingga tanggal 20 Juni 2020, ada 147 pasien yang terkonfirmasi positif COVID-19 di Bangka Belitung dan kasus terbanyak ada di Kabupaten Bangka, yakni 57 pasien terkonfirmasi positif. Kalau dikerucutkan lagi, sebarannya ada di 6 kecamatan. Hanya 2 kecamatan yang belum terkonfirmasi positif COVID-19, yakni Kecamatan Bakam dan Kecamatan Riau Silip. Dari beberapa kecamatan di Kabupaten Bangka yang sudah terkonfirmasi positif, kasusnya juga menyentuh level lokal desa. Untuk itu, desa-desa dapat melakukan penyesuaian program penanganan dan pencegahan COVID-19 sesuai dengan situasi yang terjadi. Bagi desa-desa yang terdampak, antisipasi protokolnya pemerintah desa harus berpedoman instruksi pelaksanaan Gugus Tugas Penanganan COVID-19 (Kemendagri, 2020).

Desa Bukit Layang yang dijadikan lokus pengabdian ada di Kecamatan Bakam Kabupaten Bangka. Aksesnya lebih dekat dengan kecamatan Pemali sebagai 
kecamatan penyumbang kasus terkonfirmasi positif COVID-19 paling banyak di Kabupaten Bangka. Untuk itu, perlu dioptimalkan sosialisasi tatanan kebiasaan baru. Penyuluhan yang akan dilakukan sesuai juga dengan arahan Presiden, yakni perlunya adaptasi tatanan kebiasaan baru agar masyarakat produktif di tengah pandemi (Kompas, 2020). Arahan tersebut antara lain pentingnya prakondisi yang ketat, pentingnya perhitungan yang cermat dilakukan oleh pihak desa dalam mengambil kebijakan didasarkan data dan fakta yang aktual, penentuan prioritas yang aksesnya bakal dibuka, konsolidasi dan koordinasi yang dilakukan kepala desa sampai ke level rukun tetangga, dan perlunya evaluasi rutin dalam menyambut tatanan kebiasaan baru tersebut.

Tatanan kebiasaan baru menjadi upaya menjembatani pembangunan kesehatan dan ekonomi akibat pandemi COVID-19 yang belum jelas kapan selesainya. Adaptasi tatanan kebiasaan baru ditengah pandemi COVID-19 dilakukan oleh berbagai tingkatan pemerintahan dan beberapa pihak secara kolaboratif, tak terkecuali peran perguruan tinggi dalam dharma pengabdian kepada masyarakat. Salah satunya yang dilakukan oleh tim Pengabdian kepada Masyarakat STISIPOL Pahlawan 12 dalam memberi Penyuluhan adaptasi tatanan kebiasaan baru desa tangguh COVID-19 di Desa Bukit Layang Kabupaten Bangka. Berdasarkan dinamika kebijakan dalam penanganan pandemi COVID-19 inilah, maka tim Pengabdian kepada Masyarakat Tematik COVID-19 melaksanakan kegiatan ini di Desa Bukit Layang, Kecamatan Bakam, Kabupaten Bangka.

\section{B. Metode Pelaksanaan}

1. Penjajakan dan Penyiapan Peserta

Pelaksanaan kegiatan Pengabdian kepada Masyarakat Tematik COVID-19 dengan topik penyuluhan adaptasi kebiasaan baru desa tangguh COVID-19 di Desa Bukit Layang Kecamatan Bakam Kabupaten Bangka dilaksanakan dengan beberapa tahap pada saat penjajakan, yakni: 


\section{a. Tahap Pertama}

Pada tahap ini, tim pengabdian kepada masyarakat melakukan komunikasi via telepon dengan Kepala Desa Bukit Layang, Kecamatan Bakam terkait rencana kegiatan pengabdian. Setelah mendapat persetujuan, tim berkirim surat secara administratif kepada kepala desa untuk meminta kesediaan dan menyiapkan peserta yang akan terlibat dalam penyuluhan. Adapun peserta yang kami minta adalah para relawan desa COVID-19. Pada tahap ini, juga dilakukan penandatanganan kontrak pelaksanaan program dibawah bidang Pengabdian Kepada Masyarakat STISIPOL Pahlawan 12.

b. Tahap Kedua

Setelah melaksanakan kontrak pelaksanaan program pengabdian kepada masyarakat dan mendapat persetujuan dari Desa yang akan kami laksanakan program tersebut, pada tahap ini tim pengabdian kepada masyarakat mulai melakukan pendataan peserta penyuluhan. Pendataan peserta sangat terbatas mengingat belum dibolehkan untuk mengumpul peserta dalam jumlah banyak. Adapun peserta penyuluhan adalah yang tergabung dalam relawan desa yakni Kepala Desa, Ketua Badan Permusyawaratan Desa (BPD), Perangkat Desa, Anggota BPD, Kepala Dusun, Ketua Rukun Warga (RW), Ketua Rukun Tetangga (RT), Pendamping Lokal Desa, Bidan Desa, Tokoh Agama, Karang Taruna, Pemberdayaan Kesejahteraan Keluarga (PKK) dan Tokoh Masyarakat. Setelah itu, kami berkirim surat langsung ke Kepala Desa dan survei awal lokasi yang akan dilaksanakan kegiatan. Dalam pendataan ini, sembari mengantar surat undangan, kami menjelaskan bentuk kegiatan yang akan dilaksanakan. Mulai dari pertemuan terbatas dengan mengedepankan protokol kesehatan COVID-19, presentasi materi, diskusi terarah hingga pembagian TOR (Term Of Reference). 


\section{c. Tahap Ketiga}

Pada tahap ini, tim pengabdian kepada masyarakat berkirim surat ke Gugus Tugas COVID-19 Kabupaten Bangka. Surat tersebut berupa permohonan narasumber untuk mendampingi narasumber dari STISIPOL Pahlawan 12. Setelah berkirim surat dan kemudian direspon oleh Gugus Tugas COVID-19 Kabupaten Bangka dengan mengirim juru bicara COVID-19 Kabupaten Bangka, Bapak Boy Yandra, S.Km menjadi narasumber tambahan. Beliau akan menyampaikan kondisi eksisting COVID-19 di Kabupaten Bangka dan sekaligus menyampaikan kesiapan pemerintah daerah dalam menyambut tatanan kebiasaan baru tersebut.

\section{d. Tahap Keempat}

Pada tahap ini, tim pengabdian kepada masyarakat mempersiapkan kebutuhan penyelenggaraan pengabdian. Selain menyiapkan kebutuhan teknis, seperti transportasi ke lokasi pengabdian, spanduk, absensi, snack, copyan kuisioner dan masker, tim juga melakukan pembagian kerja saat di lapangan. Adapun pembagian kerja tim terdiri dari seksi transportasi, seksi konsumsi, seksi acara, dan seksi dokumentasi. Adapun materi yang disiapkan terdiri dari 2 materi. Pertama, Dosen STISIPOL Pahlawan 12 akan menyampaikan tentang adaptasi tatanan kebiasaan baru desa tangguh COVID-19. Kedua, juru bicara Gugus Tugas COVID-19 Kabupaten Bangka akan menyampaikan kondisi eksisting COVID-19 di Kabupaten Bangka, persiapan tatanan kebiasaan baru dan upaya penanganannya.

\section{Rekrutmen Peserta Dari Mahasiswa}

Rekrutmen peserta dalam kegiatan Pengabdian kepada Masyarakat Tematik COVID-19 ini dengan melibatkan mahasiswa dari Ilmu Administrasi Negara dan mahasiswa Ilmu Komunikasi. Proses rekrutmen dengan cara melihat keaktifan mahasiswa dalam menjalankan kegiatan kemahasiswaan, prestasi akademik dan cara berkomunikasi kepada masyarakat luas. 
Keterlibatan mahasiswa Ilmu Administrasi Negara dan mahasiswa Ilmu Komunikasi karena relevan dengan bidang ilmu yang mereka tempuh di bangku kuliah. Mulai dari Mata Kuliah Pengantar Ilmu Administrasi Negara, Sistem Pemerintahan Desa, Kebijakan Publik, Dasar-Dasar Komunikasi dan Komunikasi Resiko.

\section{Pembekalan Mahasiswa}

Sebelum mahasiswa terjun ke lapangan untuk mendampingi Pengabdian kepada Masyarakat Tematik COVID-19, para mahasiswa dibekali terlebih dahulu tentang sikap, pengetahuan, cara berkomunikasi dan berinteraksi dengan masyarakat sasaran, keterampilan umum maupun keterampilan khusus jika sudah berada di lapangan. Pembekalan dilakukan selama 1 (satu) hari sebelum pelaksanaan kegiatan Pengabdian Kepada Masyakarat Tematik COVID-19.

4. Lokasi Pengabdian Kepada Masyarakat Tematik COVID-19

a. Lokasi

Kegiatan Pengabdian kepada Masyarakat Tematik COVID-19 dilaksanakan di Desa Bukit Layang, Kecamatan Bakam, Kabupaten Bangka.

b. Sasaran

Sasaran kegiatan penyuluhan adaptasi tatanan kebiasaan baru desa tangguh COVID-19 di Desa Bukit Layang, Kecamatan Bakam, Kabupaten Bangka adalah kelompok masyarakat yang tergabung dalam relawan desa COVID-19 sebagaimana tertuang dalam SK Kepala Desa Bukit Layang Tanggal 27 Maret 2020 Nomor: 188.4/38/SK/19.01.06.2008/2020 tentang Pembentukan Relawan Desa COVID-19 Desa Bukit Layang Kecamatan Bakam Tahun 2020. Adapun relawan desa tersebut diketuai Kepala Desa, wakil ketua berasal dari Ketua BPD, dan anggotanya berasal dari Perangkat Desa, Anggota BPD, 
Kepala Dusun, Ketua RW, Ketua RT, Pendamping Lokal Desa, Bidan

Desa, Tokoh Agama, Karang Taruna, PKK dan Tokoh Masyarakat.

5. Pelaksanaan Kegiatan

Pelaksanaan kegiatan Pengabdian kepada Masyarakat Tematik COVID-19 dilaksanakan pada minggu kedua Juni 2020, dengan rincian kegiatan sebagai berikut :

Tabel 1. Pelaksanaan Kegiatan Pengabdian kepada Masyarakat

\begin{tabular}{|l|l|l|l|}
\hline No & Jenis Kegiatan & Waktu & Keterangan \\
\hline 1 & $\begin{array}{l}\text { Sosialisasi Program } \\
\text { Pengabdian kepada } \\
\text { Masyarakat Tematik COVID- } \\
19\end{array}$ & 14 Juni 2020 & $\begin{array}{l}\text { Dosen pelaksana } \\
\text { pengabdian } \\
\text { kepada } \\
\text { masyarakat }\end{array}$ \\
\hline 2 & $\begin{array}{l}\text { Implementasi Program } \\
\text { Pengabdian kepada } \\
\text { Masyarakat Tematik COVID- } \\
19\end{array}$ & 15 Juni 2020 & $\begin{array}{l}\text { Tim Pengabdian } \\
\text { kepada } \\
\text { Masyarakat }\end{array}$ \\
\hline 3 & Monitoring dan Evaluasi & 15 Juni 2020 & $\begin{array}{l}\text { Pembagian } \\
\text { Kuisioner } \\
\text { penilaian resiko } \\
\text { pribadi terkait } \\
\text { Covid-19 }\end{array}$ \\
\hline
\end{tabular}

\section{Hasil dan Pembahasan}

\section{Gambaran Umum Desa Bukit Layang}

Desa Bukit Layang merupakan salah satu desa yang berada di Kecamatan Bakam Kabupaten Bangka yang mempunyai luas wilayah $25.270 \mathrm{~km}^{2}$ dengan batas-batas administrasi sebagai berikut:

- Sebelah Utara berbatasan dengan desa Pugul/Cit

- Sebelah Selatan berbatasan dengan desa Mabat

- Sebelah Barat berbatasan dengan desa Berbura, dan

- Sebelah Timur berbatasan dengan desa Air Duren.

Secara geografis Desa Bukit Layang berbentuk dataran rendah dengan kondisi tanah sedikit bergelombang. Desa Bukit Layang mempunyai tipologi 
sebagai desa perkebunan yang dicirikan oleh sebagian besar penduduknya mempunyai mata pencaharian dari kebun sawit, kebun karet, dan kebun lada. Adapun visi Desa Bukit Layang yaitu Terciptanya Masyarakat Bukit Layang Yang Tentram, Maju, Makmur, dan Berkeadilan. Desa Bukit Layang, Kecamatan Bakam Kabupaten Bangka, Kepulauan Bangka Belitung memiliki jarak tempuh sekitar 30 menit dari STISIPOL Pahlawan 12.

\subsection{Pemerintah Desa Bukit Layang}

Pemerintah Desa terdiri dari Kepala Desa yang dibantu Perangkat Desa dalam urusan penyelenggaraan Pemerintahan Desa. Perangkat Desa terdiri atas Sekretaris Desa dan Perangkat Desa lainnya yakni unsur sekretariat desa, pelaksana teknis dan unsur kewilayahan. Adapun struktur organisasi Pemerintah Desa Bukit Layang Kecamatan Bakam Kabupaten Bangka Provinsi Kepulauan Bangka Belitung tahun 2020 adalah :

Gambar 1.

Struktur Organisasi Pemerintah Desa Bukit Layang Tahun 2020



Sumber : diolah penulis (2020) 
Tabel 2.

Data Kepala Desa dan Perangkat Desa Bukit Layang Tahun 2020

\begin{tabular}{|c|l|c|c|}
\hline No & \multicolumn{1}{|c|}{ Nama } & Jabatan & $\begin{array}{c}\text { Pendidikan } \\
\text { Terakhir }\end{array}$ \\
\hline 1. & Andry & Kepala Desa & SMA/Sederajat \\
\hline 2. & Afrizal Paurasi & Sekretaris Desa & DIII \\
\hline 3. & Solidin & Kasi Pemerintahan & SMA/Sederajat \\
\hline 4. & Mika & Kasi Kesejahteraan & SMA/Sederajat \\
\hline 5. & Hikmah Mukta Mira & Kasi Pelayanan & S1 \\
\hline 6. & Muhammad Kholil & Kaur TU \& Umum & SMA/Sederajat \\
\hline 7. & Seno Prayudi & Kaur Keuangan & S1 \\
\hline 8. & Syahrezy Fajar & Kaur Perencanaan & SMA/Sederajat \\
\hline 9. & Majidan & Kepala Dusun I & SMA/Sederajat \\
\hline 10. & Ruslan & Kepala Dusun II & SMA/Sederajat \\
\hline 11. & Lista & Kepala Dusun III & SMA/Sederajat \\
\hline 12. & Dedi & Kepala Dusun IV & SMA/Sederajat \\
\hline 13. & M. Rendra & Kepala Dusun V & SMA/Sederajat \\
\hline 14. & Surono & Kepala Dusun VI & SMA/Sederajat \\
\hline 15. & Toni Kristian & Kepala Dusun VII & SMA/Sederajat \\
\hline
\end{tabular}

Sumber : diolah penulis (2020)

\subsection{Badan Permusyawaratan Desa Bukit Layang}

Badan Permusyawaratan Desa (BPD) juga berkedudukan sebagai unsur penyelenggara Pemerintahan Desa bersama Pemerintah Desa. Anggota BPD merupakan wakil dari penduduk desa yang dipilih secara langsung oleh masyarakat desa berdasarkan keterwakilan wilayah. Adapun struktur organisasi BPD Bukit Layang 
Kecamatan Bakam Kabupaten Bangka Provinsi Kepulauan Bangka Belitung periode 2019-2025 adalah:

Gambar 2.

Struktur Organisasi BPD Bukit Layang Periode 2019-2025

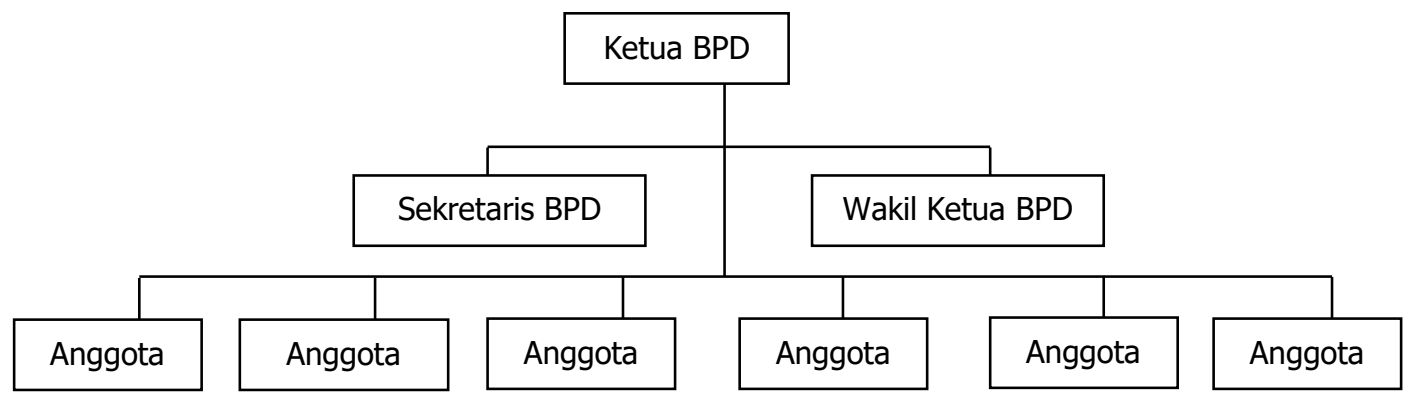

Sumber : diolah penulis (2020)

Tabel 3.

Data Anggota BPD Bukit Layang Periode 2019-2025

\begin{tabular}{|c|l|c|c|}
\hline No & \multicolumn{1}{|c|}{ Nama } & Jabatan & $\begin{array}{c}\text { Pendidikan } \\
\text { Terakhir }\end{array}$ \\
\hline 1. & Teguh Arianto & Ketua BPD & SMA/Sederajat \\
\hline 2. & Ivan Novian & Wakil Ketua BPD & SMA/Sederajat \\
\hline 3. & Devi Yanti & Sekretaris BPD & SMA/Sederajat \\
\hline 4. & Joko Susanto & Anggota BPD & SMA/Sederajat \\
\hline 5. & Damhir & Anggota BPD & SMA/Sederajat \\
\hline 6. & Aidil Adhar & Anggota BPD & SMA/Sederajat \\
\hline 7. & Sufui & Anggota BPD & SMA/Sederajat \\
\hline 8. & M. Firdaus Yusuf & Anggota BPD & SMA/Sederajat \\
\hline 9. & Lie Sen Sen & Anggota BPD & SMA/Sederajat \\
\hline
\end{tabular}

Sumber : diolah penulis (2020)

\section{Konsep Desa Tangguh COVID-19}


Mengacu kepada surat edaran Menteri Desa, Pembangunan Daerah Tertinggal dan Transmigrasi Republik Indonesia Nomor 8 Tahun 2020 tentang Desa Tanggap COVID-19, disebutkan bahwa desa tanggap COVID-19 membentuk relawan desa lawan COVID-19 dengan tugas melakukan pencegahan, penanganan terhadap warga desa korban COVID-19 dan senantiasa melakukan koordinasi secara intensif dengan pemerintah kabupaten/kota.

Sementara, konsep desa tangguh COVID-19 yang digagas oleh tim pengabdian kepada masyarakat STISIPOL Pahlawan 12 adalah desa yang senantiasa produktif dalam pemberdayaan masyarakat di tengah COVID-19 melanda desa tersebut. Artinya, konsep desa tangguh COVID-19 tidak sebatas pada aktivitas pencegahan dan penanganan, melainkan ada inovasi-inovasi dan produktivitas yang dilakukan dalam kaitannya mencegah dan menangani COVID-19 itu sendiri. Adapun konsep desa tangguh COVID-19 itu terdiri dari Desa Kreatif yakni Pendampingan UKM terdampak dengan memproduksi barang yang sesuai kebutuhan. Desa Hijau, yakni pemberdayaan warga masyarakat dalam mengolah lahan pekarangan untuk sayuran dan tanaman obat. Desa Peduli yakni, pemberdayaan masyarakat dalam peningkatan kepedulian kepada warga yang terdampak COVID-19. Desa Pintar, yakni pemberdayaan keluarga dalam pendampingan belajar anakanak sekolah secara online, mengelola waktu belajar dan bermain yang menyenangkan dan Desa Sehat yakni, pemberdayaan posyandu sebagai garda terdepan menghadapi COVID-19 dengan menerapkan physical distancing, deteksi dini penyakit, penerapan pola hidup bersih dan sehat.

Pemberdayaan masyarakat dalam pencegahan COVID-19 adalah segala upaya yang dilakukan oleh seluruh komponen masyarakat dengan menggali potensi yang dimiliki masyarakat agar berdaya dan mampu berperan serta mencegah penularan Covid-19. Pemberdayaan masyarakat tersebut berupa menyampaikan informasi pencegahan COVID-19 kepada warga melalui 
pendekatan budaya/agama (langsung atau online), memasukkan materi COVID-19 dalam ceramah/tausiah yang diberikan, mengajak warga berpartisipasi dalam upaya pencegahan COVID-19, membantu Ketua RT/RW/Kepala Dusun dalam mengedukasi warga agar tidak memberi stigma buruk kepada Orang Dalam Pemantauan (ODP) dan Pasien Dalam Pengawasan (PDP), menjaga jarak fisik: dilarang berdekatan dengan orang atau mengatur jarak minimal 1-2 meter, hindari transportasi publik, tetap berada di rumah saja, dan saling mengingatkan sesama warga untuk menjaga kebersihan dan keamanan lingkungan. Secara garis besar, konsep desa tangguh COVID-19 tersebut diimplementasikan di Desa Bukit Layang, Kecamatan Bakam, Kabupaten Bangka.

\section{Pemahaman Masyarakat Terkait Konsep Tatanan Kebiasaan Baru}

Dalam menghadapi konsep tatanan kebiasaan baru, perlu penyampaian informasi mengenai hal - hal yang belum dan tidak diketahui oleh masyarakat Desa Bukit Layang, seperti informasi untuk selalu mentaati protokol kesehatan COVID-19 jika sedang beraktivitas. Untuk itu perlunya diskusi interaktif pada kegiatan Pengabdian Kepada Masyarakat Tematik COVID-19. Masyarakat Desa Bukit Layang perlu kesiapan tatanan kebiasaan baru meskipun saat ini Kabupaten Bangka belum siap untuk melaksanakan tatanan kebiasaan baru tersebut karena masih terjadinya transmisi lokal dengan adanya penambahan pasien yang terkonfirmasi COVID-19. Informasi dari pusat memberitahukan bahwa memang belum saatnya melaksanakan tatanan kebiasaan baru akan tetapi perlu dipersiapkan dari sekarang.

Secara keseluruhan, setelah kegiatan Pengabdian Kepada Masyarakat Tematik COVID-19, masyarakat di Desa Bukit Layang memahami konsep tatanan kebiasaan baru. Sebelumnya, masyarakat di Desa Bukit Layang sama sekali tidak memahami konsep tatanan kebiasaan baru tersebut. Tak hanya itu, konsep tatanan kebiasaan baru diikuti dengan menjalankan protokol kesehatan 
yaitu cuci tangan dengan sabun disertai air mengalir, menggunakan masker, dan tetap konsisten menjaga jarak. Tak hanya itu, jika ada kasus COVID-19 di desa tersebut, agar untuk melapor ke level kecamatan termasuk apabila ingin melaksanakan kegiatan-kegiatan seperti kegiatan keagamaan dan kegiatan yang mengakibatkan masyarakat berinteraksi dalam jumlah banyak. Pembatasan sosial tetap dijalankan dengan tetap menerapkan protokol kesehatan COVID-19.

\section{Analisa Terhadap Hasil yang Diperoleh}

Hasil Pengabdian kepada Masyarakat Tematik COVID-19 ini menunjukkan bahwa peserta sangat antusias dalam mengikuti rangkaian kegiatan yang dilakukan. Hal ini ditandai dengan diskusi yang begitu terarah terkait tatanan kebiasaan baru. Masyarakat Desa Bukit Layang sebagai peserta banyak bertanya tentang kesiapan pemerintah dalam memformulasikan kebijakan tatanan kebiasaan baru. Tak hanya itu, masyarakat juga bertanya bagaimana menjalankan tatanan kebiasaan baru ditengah-tengah pandemi yang masih berlangsung hingga saat ini.

\section{Evaluasi Kegiatan}

Evaluasi kegiatan Pengabdian kepada Masyarakat Tematik COVID-19 ini dilakukan dengan membagikan kuisioner penilaian resiko pribadi terkait COVID-19 sebagaimana tertuang dalam lampiran Surat Edaran Menteri Desa, Pembangunan Daerah Tertinggal dan Transmigrasi Republik Indonesia Nomor 8 Tahun 2020 tentang Desa Tanggap COVID-19 dan Penegasan Padat Karya Tunai Desa. Kuisioner yang akan dibagikan memiliki rentang point penilaian. Adapun rentang point penilaian masing-masing indikator resiko mulai dari resiko rendah, resiko sedang dan resiko tinggi yakni, untuk indikator resiko rendah pada point 0-7, indikator resiko sedang pada point 8-14 dan indikator resiko tinggi pada point $15-21$. 
Tabel 4. Penilaian Resiko Pribadi Terkait COVID-19 di Desa Bukit Layang

\begin{tabular}{|c|c|c|c|}
\hline No & Nama & Jabatan & Nilai \\
\hline 1 & Andry & Kepala Desa & 6 \\
\hline 2 & Afrizal Paurasi & Sekretaris Desa & 5 \\
\hline 3 & Zamzari & BUMDEs & 6 \\
\hline 4 & Vita Apriyani & PKK & 6 \\
\hline 5 & Windi Astuti & Kasi Pelayanan & 5 \\
\hline 6 & Muhammad Kholil & Kaur TU \& Umum & 6 \\
\hline 7 & M. Firdaus Yusuf & Tokoh Masyarakat & 6 \\
\hline 8 & Syahrezy Fajar & Kaur Perencanaan & 6 \\
\hline 9 & Majidan & Kepala Dusun I & 5 \\
\hline 10 & Ruslan & Kepala Dusun II & 6 \\
\hline 11 & Lista & Kepala Dusun III & 6 \\
\hline 12 & Dedi & Kepala Dusun IV & 5 \\
\hline 13 & M. Rendra & Kepala Dusun V & 7 \\
\hline 14 & Surono & Kepala Dusun VI & 6 \\
\hline 15 & Toni Kristian & Kepala Dusun VII & 6 \\
\hline 16 & Teguh Arianto & Ketua BPD & 6 \\
\hline 17 & Ivan Novian & Wakil Ketua BPD & 4 \\
\hline 18 & Lie Sen Sen & Anggota BPD & 5 \\
\hline 19 & Aidil Kohar & Karang Taruna & 5 \\
\hline 20 & Devi Yanti & Sekretaris BPD & 3 \\
\hline
\end{tabular}

Berdasarkan hasil kuisioner yang diisi oleh peserta Pengabdian kepada Masyarakat Tematik COVID-19 dan kemudian diolah oleh tim Pengabdian kepada Masyarakat Tematik COVID-19, bahwa penilaian resiko pribadi terkait COVID-19 di Desa Bukit Layang Kecamatan Bakam Kabupaten Bangka secara keseluruhan masuk dalam kategori resiko rendah. Dengan demikian, masyarakat di desa tersebut sangat memahami protokol kesehatan COVID-19 
dan berdasarkan materi yang disampaikan oleh dua narasumber, masyarakat desa memahami konsep tatanan kebiasaan baru di tengah-tengah pandemi. Oleh karena itu, masyarakat desa bersiap untuk beradaptasi dalam tatanan kebiasaan baru di saat pandemi masih berlangsung.

\section{Kesimpulan Dan Saran}

\section{Kesimpulan}

Adapun kesimpulan pada kegiatan Pengabdian kepada Masyarakat Tematik COVID-19 di Desa Bukit Layang, Kecamatan Bakam, Kabupaten Bangka adalah sebagai berikut :

a. Masyarakat Desa Bukit Layang sebelumnya belum memahami mengenai konsep tatanan kebiasaan baru yang sedang diformulasikan pemerintah dalam menyikapi COVID-19 yang masih terjadi di Indonesia saat ini.

b. Melalui kegiatan Pengabdian kepada Masyarakat Tematik COVID-19 yang diselenggarakan oleh tim pengabdian masyarakat STISIPOL Pahlawan 12, masyarakat mulai memahami konsep tatanan kebiasaan baru dengan tetap menerapkan protokol kesehatan COVID-19, terutama trilogi pencegahan COVID-19 mulai dari menggunakan masker, jaga jarak dan sering cuci tangan dengan air bersih yang mengalir.

\section{Saran}

Saran yang diberikan pada kegiatan Pengabdian kepada Masyarakat Tematik COVID-19 di Desa Bukit Layang, Kecamatan Bakam, Kabupaten Bangka adalah sebagai berikut :

a. Agar masyarakat lebih patuh terhadap protokol kesehatan COVID-19 yang dianjurkan pemerintah mulai dari memakai masker saat beraktivitas, selalu menjaga jarak dan sering mencuci tangan dalam menjalankan aktivitas pada tatanan kebiasaan baru.

b. Agar masyarakat lebih meningkatkan kesadaran dalam hal pencegahan, mitigasi maupun ketahanan dalam memperkuat sistem ketahanan tubuh sehingga tidak 
mudah terjangkit virus COVID-19 dan melaksanakan kegiatan dalam tatanan kebiasaan baru berjalan dengan lancar.

c. Agar masyarakat tetap mengikuti nasihat otoritas bidang kesehatan dan masyarakat tidak mudah menerima informasi yang tidak valid mengenai COVID19.

d. Perlu penguatan literasi terkait wabah virus COVID-19, tatanan kebiasaan baru dan membangun mekanisme komunikasi dan koordinasi yang efektif di tingkat lokal desa dalam sektor kesehatan, dimulai dari membentuk tim koodinasi kedaruratan kesehatan, panduan strategi dalam tahap respon emergensi hingga komunikasi resiko.

e. Pemerintah desa perlu menetapkan peraturan desa sebagai landasan tatanan kebiasaan baru desa dengan mengkompilasi protokol kesehatan dari berbagai lembaga untuk desa.

\section{E. Ucapan Terima Kasih}

Kami mengucapkan terima kasih kepada Sekolah Tinggi Ilmu Sosial dan Ilmu Politik Pahlawan 12 Sungailiat melalui bidang pengabdian kepada masyarakat karena telah mengucurkan bantuan dana dalam pelaksanaan kegiatan ini. Ucapan yang sama kami sampaikan pula kepada para mahasiswa yang sudah terlibat aktif di lapangan dalam menyukseskan kegiatan Pengabdian kepada Masyarakat Tematik COVID-19.

\section{DAFTAR PUSTAKA}

Mas'udi, Wawan dkk (2020). Tata Kelola Penanganan Covid-19 di Indonesia: Kajian Awal. Yogyakarta: Gajah Mada University Press

Kementerian Dalam Negeri (2020). Pedoman Umum Menghadapi Pandemi Covid-19 Bagi Pemerintah Daerah: Pencegahan, Pengendalian, Diagnosis dan Manajemen. Jakarta: Tim Kerja Kemendagri

Kompas (2020), https://nasional.kompas.com/read/2020/06/11/10370371/lima-arahanjokowi-agar-tak-ada-gelombang-kedua-covid-19?page=all, diakses pada tanggal 25 Juni 2020

Surat Edaran Menteri Desa, Pembangunan Daerah Tertinggal, dan Transmigrasi Republik Indonesia Nomor 8 Tahun 2020 tentang Desa Tanggap Covid-19 dan Penegasan Padat Karya Tunai Desa. 